This policy brings London and Whipsnade into line with almost all continental zoos, which have already banned feeding by visitors. Chester and Edinburgh also enforce the ban, and Bristol will be doing so at the beginning of next year. Zoos which have already adopted the policy have found that animals are much fitter and that the volume of deposited litter has decreased considerably. The problem of educating the public to resist throwing buns, nuts and other food to the animals is considerable. As well as the leaflets there will be more "no feeding" notices, and, although nobody will be turned out of the zoo for feeding the animals, offenders will be asked to stop by watchful keepers. Nevertheless, London Zoo expects it to be three years before its annual total of two million visitors are all persuaded to observe the ban.

\section{Inexpensive Technology}

A British group set up to promote technological development in backward parts of the world has just published an unusual report. Instead of familiar and extravagant declarations of what could be done by setting up large nuclear power stations linked to desalination plants, or by harvesting the sea, the report concentrates on much more mundane pieces of equipment. The group is the Intermediate Technology Development Group Ltd, and the report-Tools for Progress-lists agricultural and industrial equipment which can be bought for modest amounts, within the budgets of developing countries. The director of the group, Dr E. F. Schumacher, says in the introduction to the report that "It is easy to think of the progress that would be possible if the majority of the world's peasants had the means of making full use of modern science, and the necessary knowledge and method to boot. But this means solving the problem by assuming it away. The crucial question is rather how to help the majority to help themselves."

The group has set out to do this by making people aware that cheap methods, tools and equipment do exist, and that these can be made available where they are needed. Tools for Progress is the result of a survey made of British manufacturers, and includes short descriptions and pictures of most of the tools which fall into the low cost category. The guide also lists the manufacturing agents in developing countries, and British organizations concerned with development problems. Three thousand copies of the booklet are to be distributed to banks, co-operatives, government officials and the like in developing countries, and further copies can be had for $15 s$. each.

The guide is a cheerful mixture of products, some of them looking rather old-fashioned. But all look purposeful and sturdy, and where prices are quoted (it is a pity they are not given throughout) they seem reasonable. It is possible, for example, to buy a windmill pump capable of pumping 1,130 gallons per hour for $£ 120$, from H. J. Godwin Ltd. A Kentish foot loom can be bought from Douglas Andrew Ltd for $£ 80$. The group plans to produce revised editions of the guide periodically, and would welcome helpful suggestions.

\section{Investigating the Earth}

THe International Upper Mantle Project, begun in 1963 to co-ordinate international research into the geophysics of the region just below the Earth's crust, is now well under way. Among the techniques used have been the measurement of heat in deep bore holes, aeromagnetics, and the measurement of gravity from orbiting satellites, the last of these particularly requiring the co-operation of many countries. Large numbers of research workers have converged, naturally enough, on the East African rift system and the MidAtlantic Ridge, but geophysical understanding of great areas of the world has already been increased. The interim report on the Canadian effort, for example, is able to announce that: "Canadian scientists can begin to talk knowledgeably of the geological and geophysical properties of the entire Canadian crust".

It would, perhaps, be invidious to mention any individual piece of research completed so far, but as far as Britain is concerned, there are a number of projects, either approved or under consideration, which promise to be of great interest. One of these is the planned aeromagnetic survey of the rift valley in the Red Sea and Ethiopia. This is a region peculiarly unsuited to ground observation but in which there may well be magnetic anomalies similar to those discovered in the Mid-Atlantic Ridge, where it was found that the magnetic irregularities were mirror-images of each other on either side of the ridge. The Natural Environment Research Council has given a grant to support this work. There is also a plan, not yet approved by NERC, to take measurements across the rift valley further south over a period of years, and so detect earth movements, a technique which has provided encouraging results in Iceland. A possible experiment on the rift would be carried out by associate teams from some British universities, including Birmingham and Durham. This plan is to investigate the geology of Lake Victoria by analysing the seismic effects of explosives dropped into the lake.

\section{National Parks}

The National Parks Commission has in the past few months produced reports on the Brecon Beacons and the coasts of Hampshire and the Isle of Wight. Both documents are concerned with conservation and each is one of a series on similar subjects. The detailed guide to the Brecon Beacons is the fifth in a series of ten on the National Parks, while the report of the Regional Coastal Conference on Hampshire and Isle of Wight Coasts is the second of a series on coastal preservation and development. National Park guides are designed for the visitor, to enable him to understand and appreciate the countryside better. Coastal conferences, on the other hand, are designed to produce a comprehensive survey of the whole coastline so that a co-ordinated policy can be developed.

The National Park in the Brecon Beacons, with more sheep than people in the upland regions, is unindustrialized and largely unspoilt. The authors of the guide hope that the visitors who come will keep it that way, but endeavour to increase appreciation of the area with this detailed description of things to see, whether living or historical, and things to do, in the way of pony trekking or caving. The Palacozoic rocks of the area are described; many of the 200 kinds of birds and their localities are listed, as are animals, insects and flora. Scheduled ancient monuments, places of interest and Welsh names in the park are 